\title{
Pola Interaksi Antar-lembaga dan Reformasi Tata Kelola Keamanan Maritim Indonesia: Bakamla RI
}

\author{
${ }^{1}$ Adi Wibawa, ${ }^{2}$ Muhammad Ridha Iswardhana, ${ }^{3}$ Hidayat Chusnul Chotimah \\ ${ }^{1}$ Universitas Teknologi Yogyakarta; adi.wibawa@staff.uty.ac.id \\ ${ }^{2}$ Universitas Teknologi Yogyakarta; muhammad.ridha@staff.uty.ac.id \\ ${ }^{3}$ Universitas Teknologi Yogyakarta; hidayat.chotimah@staff.uty.ac.id
}

\begin{abstract}
Maritime security is an essential aspect for an archipelagic country like Indonesia. In addition, as stated by President Joko Widodo, maritime defense forces are also one of the five pillars in realizing Indonesia as the "World Maritime Axis." However, unfortunately, there are still many problems that we can identify in the management of Indonesian maritime security and defense. One of the most fundamental problems is many authorized ministries/agencies, causing overlapping authorities in our territorial waters. This study aims to determine the pattern of interaction between ministries/agencies and how the government should carry out the government towards the ministry/institution in question. The researcher uses qualitative methods, and the data used are secondary data obtained from books, journal articles, and other sources that can be accessed online. In analyzing the interaction pattern between ministries/agencies, the researcher uses the theory of inter-agency working. As a result, the interaction between the competent ministries/agencies has not shown good synergy in maintaining maritime security in Indonesian waters. Furthermore, the era of technological disruption has demanded bureaucratic reform 4.0 by emphasizing three (3) things, including innovation, collaboration, and maximizing the use of information and communication technology. The researcher concludes that there is a need to reform Indonesia's maritime security governance by strengthening the synergy between ministries/agencies or even simplifying the number of authorized ministries/agencies based on the single agency multi-task system. In addition, it is necessary to use quality technology to support effectiveness and efficiency in protecting the security of marine waters in Indonesia.
\end{abstract}

Keywords: Bakamla, Governance, Indonesia, Institutions, Maritime Security.

\section{Pendahuluan}

Wilayah perairan merupakan bagian yang penting bagi Negara Kesatuan Republik Indonesia. Sejak disahkannya Konvensi Hukum Laut Perserikatan Bangsa-Bangsa pada tahun 1982. Indonesia secara resmi diakui dunia sebagai Archipelagic State atau negara kepulauan. Jauh sebelum diakui dunia, tepatnya pada 13 Desember 1957. Indonesia telah mendeklarasikan bahwa Pemerintah Indonesia memiliki kedaulatan mutlak atas seluruh perairan yang terletak dalam garis-garis pangkal yang ditarik di antara pulau-pulau terluar wilayah Indonesia melalui Deklarasi Djuanda. Deklarasi tersebut tentu berimplikasi pada segala aktifitas yang berlangsung di atas perairan yang diklaim oleh Indonesia (Buthcher, 2017). Selain untuk tujuan melindungi kedaulatan Indonesia sebagai sebuah negara merdeka, Deklarasi Djuanda juga bermaksud untuk memastikan segala bentuk sumber daya alam dan potensi ekonomi yang ada di laut Indonesia dapat sepenuhnya dikelola secara sah oleh negara.

Keamanan maritim menjadi salah satu perhatian yang menarik berbagai pemimpin, politisi, pemangku kebijakan, dan akademisi dalam memahami fenomena yang terjadi di perairan dan wilayah laut. Keamanan maritim ini cenderung bersifat luas yang pada akibatnya belum memiliki kebakuan dalam memahami definisi resmi dari konsep ini. Diskursus yang terjadi lebih banyak merupakan penggunaan istilah dalam hukum dan hubungan internasional. Pemahaman keamanan maritim mulai dibingkai dalam bidang keselamatan dan seiring dengan adanya berbagai ancaman dan tantangan di lautan dengan berusaha menunjukkan pada upaya prioritas 
dan penyelesaian permasalahan. Berikutnya dalam konsep ini berupaya memberikan pandangannya terhadap bidang ekonomi dan ketahanan yang berusaha menampilkan laut sebagai masa depan dunia. Lalu, konsep ini dicoba dipahami dalam spektrum yang lebih luas, yakni: pertahanan. Bahwa realitas ketka wilayah perairan laut sangat strategis bagi sebuah negara, baik saat damai maupun konflik yang selanjutnya sangat perlu diperhatikan. Pada level yang paling luas, keamanan maritim dapat ditunjukkan oleh keberadaan dan kehadiran negara di wilayah perairan nasional dan internasional (Nurdiansyah, 2018).

Lebih lanjut keamanan maritim mulai dirangkai menjadi sebuah upaya negara untuk menjaga kedaulatan dan keamanan wilayah perairan laut agar dapat mewujudkan kepentingan nasionalnya dan menghindari terjadinya bermacam ancaman, tantangan, dan pelanggaran hukum. Cara yang ditempuh oleh negara tersebut akan difokuskan pada pencegahan, pengamanan, dan pengendalian segala aktivitas di perairan laut, baik dalam kaitannya politik, ekonomi, perdagangan, pelayaran, pertahanan, dan lingkungan oleh sebuah lembaga tertentu (Iswardhana, 2021). Dalam kaitannya riset ini, penulis berupaya menghadirkan konsep ini yang dipotret dalam sudut pandang lembaga birokrasi dalam menjalankan tugasnya secara profesional di wilayah laut dalam menjaga dan melindungi wilayah laut sebagai salah satu bentuk kebijakan negara. Terdapat ide utama yang orisinal bahwa berbagai bentuk bencana, kecelakaan, dan kerawanan yang terjadi di laut tentunya dapat dicegah dan ditanggulangi apabila terdapat organisasi yang kuat dan ideal hingga dapat menciptakan keamanan maritim yang baik.

Berdasarkan data Kementerian Kelautan dan Perikanan (KKP), Indonesia memiliki 17.499 pulau dengan luas total wilayah Indonesia sekitar 7,81 juta km2. Dari total luas wilayah tersebut, 3,25 juta $\mathrm{km} 2$ adalah lautan dan 2,55 juta km2 adalah Zona Ekonomi Eksklusif. Hanya sekitar 2,01 juta km2 yang berupa daratan (Dirjen Pengelolaan Laut, 2020). Dengan kondisi seperti ini, potensi sumberdaya alam yang ada di laut Indoneisa bisa dipastikan begitu besar. Mulai dari sumberdaya mineral, pariwisata sampai perikanan. Selain itu, letak geografis Indonesia yang diapit oleh dua benua dan dua samudera juga amat vital sebagai salah satu jalur transportasi dan perdagangan internasional. Potensi-potensi tersebut pula yang mendorong Presiden Joko Widodo berambisi untuk menjadikan Indonesia sebagai Poros Maritim Dunia sejak periode pertama kepemimpinannya. Sebuah ambisi besar yang sebenarnya sudah mulai digaungkan sejak pemerintahan BJ. Habibie (Nainggolan, 2016).

Dalam menjelaskan pola interaksi yang terjalin di antara lembaga-lembaga yang berwenang di laut Indonesia, peneliti menggunakan teori inter-agency working dari Arthur Himmelman yang menyatakan bahwa ada empat pola interaksi yang dilaksanakan antar lembaga yaitu: networking, koordinasi, kerjasama dan kolaborasi. Networking berarti bahwa interaksi yang terjadi semata-mata hanya dalam bentuk pertukaran informasi. Berikutnya yang dimaskud koordinasi adalah networking namun disertai dengan adanya suatu perubahan sebagai hasil dari pertukaran informasi tersebut. Selanjutnya, kerjasama diartikan sebagai networking dan koordinasi yang disertai pembagian sumber daya di antara lembaga-lembaga yang terkait. Terakhir, kolaborasi dianggap sebagai pola interaksi paling sempurna karena merupakan gabungan ketiga unsur sebelumnya serta ditambah dengan adanya peningkatan aktivitas instansi tertentu yang saling menguntungkan instansi lainnya (Himmelman, 2002). Dari teori ini dapat diidentifikasi pola interaksi seperti apa yang terjalin di antara lembaga-lembaga tersebut di atas.

Keberadaan sejumlah lembaga/kementerian yang memiliki kewenangan serupa seperti yang terjadi dalam konteks keamanan laut di Indonesia biasa disebut sebagai Multi Agency Single Task (MAST). Konsep tata kelola ini berarti bahwa terdapat lebih dari dua lembaga yang memiliki kewenangan yang sama dalam sebuah negara. Besarnya tugas dan cakupan kewenangan biasanya menjadi alasan utama mengapa konsep ini dipilih oleh negara tersebut. Kebalikan dari MAST, konsep Single Agency Multi Task (SAMT) berarti bahwa hanya ada satu lembaga yang diberikan kewenangan menyeluruh dalam suatu lingkup birokrasi. 
Kedua konsep tersebut sama-sama memiliki kelebihan dan kekurangan. SAMT memiliki keunggulan dibanding MAST dalam hal efektivitas karena adanya kesatuan komando (unity of command) dan tidak akan ada konflik kepentingan antar-lembaga. Selain itu, SAMT juga lebih efisien secara biaya karena anggaran yang dialokasikan hanya akan terpusat pada satu lembaga. Namun demikian, SAMT menuntut adanya pelatihan dan pembinaan kapasitas sumber daya manusia yang komprehensif agar dapat menjalankan berbagai macam bentuk tugas. Hal seperti ini yang tidak dijumpai pada konsep MAST, tanggungjawab pengembangan kapasitas sumber daya manusia diserahkan pada masing-masing lembaga dan hanya terfokus pada dan hanya fokus satu aspek keahlian tetentu. Berdasarkan sudut pandang pengorganisasian, SAMT juga akan melahirkan birokrasi yang lebih gemuk karena luasnya cakupan wilayah dan kewenangan kerja. Tidak ada kepastian konsep mana yang lebih baik. Pilihan di antara konsep-konsep tersebut akan sangat bergantung pada kondisi masing-masing negara (Santosa, 2021).

Sampai saat ini penelitian yang megkaji tentang tata kelola keamanan maritim di Indonesia jumlahnya cukup terbatas. Namun demikian terdapat beberapa penelitian terdahulu yang dapat dijadikan rujukan di penelitian ini. Pertama, penelitian yang dilakukan oleh Andhika Wira Kusuma, Lukman Yudho Prakoso, dan Dohar Sianturi (2019) yang berjudul "Sinergitas Komando Armada I dan Badan Keamanan Laut Republik Indonesia dalam Strategi Pertahanan Laut Guna Memberantas Kejahatan Lintas Negara di Selat Malaka”. Dalam penelitian ini, peneliti menganalisis aspek sinergitas antara Komando Armada 1 sebagai bagian dari TNI AL dengan BAKAMLA di wilayah operasi Selat Malaka. Hasil dari penelitian menunjukkan adanya derajat sinergitas yang rendah di antara lembaga yang diteliti. Namun yang perlu dicatat dari penelitian tersebut adalah objek penelitian yang hanya terbatas pada dua lembaga (TNI Al dan BAKAMLA) dan hanya pada operasi di Selat Malaka. Sehingga hasil penelitian tersebut tidak dapat dijadikan acuan untuk mengukur interaksi kedua lembaga tersebut secara nasional dan antara kedua lembaga terebut dengan lembaga-lembaga lain seperti Polair dan KKP.

Penelitian kedua yaitu karya Ahmad Budiman (2016) yang berjudul "Urgensi Pengaturan Masalah Keamanan Laut di Indonesia" Pada penelitian ini, peneliti hanya berusaha menguraikan secara rinci potret permasalahan-permasalahan yang terjadi dalam tata kelola keamanan laut Indonesia dan perlunya pengaturan yang lebih baik di masa yang akan datang. Tata kelola yang dimaksud dalam penelitian ini lebih mengarah pada aturan perundang-undangan tanpa melihat realitas interaksi antar lembaga yang diatur berdasarkan aturan-aturan tersebut. Penelitian terakhir yaitu penelitian dengna judul "Integrasi Tata Kelola Kebijakan Pembangunan Kelautan Berkelanjutan" karya Diah Atika Apriani (2019). Tidak jauh berbeda dengan penelitian sebelumnya, penelitian ini juga menjelaskan perlunya integrasi tata kelola keamanan maritim dari sisi perundang-undangan. Peneliti menjelaskan bahwa dalam mengelola keamanan laut Indonesia, kepastian hukum merupakan suatu hal yang mutlak agar tidak terjadi konflik baik secar horizontal maupun vertikal. Namun lagi-lagi penelitian ini belum membahas secara mendalam praktik tata kelola keamanan maritim di tingkat implementasi kebijakan.

Ambisi untuk menjadikan Indonesia sebagai poros maritim tentu bukan sesuatu yang mudah untuk dicapai. Meskipun memiliki berbagai potensi keuntungan, wilayah laut Indonesia juga memiliki potensi ancaman yang tak kalah besar. Menurut Kepala Badan Keamanan Laut Republik Indonesia, Laksamana Madya TNI Aan Kurnia, setidaknya terdapat delapan ancaman yang harus dihadapi Indonesia saat ini (Ardiansyah, 2020), yaitu:

1) Pelanggaran wilayah,

2) Perompakan bersenjata,

3) Kecelakaan,

4) Kejahatan terorganisasi lintas negara, 
5) Penangkapan ikan secara ilegal,

6) Pencemaran,

7) Terorisme, dan

8) Invasi.

Berbagai ancaman tersebut harus dapat ditangani dengan baik jika Indonesia benar-benar ingin diakui sebagai negara poros maritim dunia. Besarnya potensi sekaligus ancaman yang ada di perairan Indonesia serta ambisi untuk menjadi poros maritim dunia menuntut pemerintah untuk memiliki strategi keamanan laut yang efektif dan efisien. Namun kenyataannya, tata kelola keamanan laut yang dijalankan Indonesia justru masih terkesan problematik. Banyaknya peraturan perundang-undangan menyebabkan tumpang tindih kewenangan yang dimiliki instansi-instansi pemerintah di bidang keamanan laut. Saat ini, kewenangan penjagaan kemanan laut Indonesia dimiliki oleh beberapa lembaga dan kementerian seperti Tentara Nasional Indonesia Angkatan Laut (TNI AL), Polisi Air (Polair), Bea dan Cukai, Kementrian Kelautan dan Perikanan, dan terakhir Kesatuan Penjaga Laut dan Pantai (KPLP) (Ramadhan \& Winarno, 2020). Keberdaaan sejumlah lembaga dengan kewenangan serupa tentu berpotensi menimbulkan persoalan tersendiri. Maka dari itu perlu dilakukan kajian tentang bagaimana interaksi yang terjalin di antara lembaga-lembaga tersebut dalam menjalankan tugas berat mengamankan perairan Indonesia serta menilai kemungkinan adanya reformasi tata kelola di bidang keamanan laut jika ternyata interaksi yang terjalin antar lembaga tidak berjalan dengan baik.

Dari latar belakang di atas, maka penelitian ini bertujuan untuk menganalisis bagaimana pola interaksi yang terjalin di antara lembaga-lembaga yang berwenang mengelola keamanan maritim Indonesia dan bagaimana tata kelola keamanan maritim yang seharusnya dijalankan oleh pemerintah Indonesia.

\section{Metode Penelitian}

Penelitian ini menggunakan pendekatan kualitatif deskriptif yang berupaya memberikan penjelasan secara deskriptif. Dalam riset ini peneliti menggunakan data kualitatif tentang permasalahan yang akan diteliti. Adaanya kepastian jawaban lebih mendalam terkait realitas yang problematika riset melalui publikasi resmi individu, kelompok, maupun organisasi merupakan latar belakang pemilihan penelitian secara kualitatif. Data yang akan digunakan dalam penelitian ini terdiri dari sekunder. Data sekunder tersebut berasal dari studi literatur dan/atau berbagai macam publikasi resmi dan kredibel yang berasal dari cetak maupun internet.

\section{Hasil dan Pembahasan}

Sebagai sebuah negara yang luas dan memiliki populasi besar, selama ini Indonesia diyakini membutuhkan bentuk birokrasi yang gemuk yang ditandai dengan banyaknya jumlah instansi yang ada di pemerintahan. Akan tetapi, konsep negara kesatuan juga menuntut adanya integrasi nasional di berbagai bidang, termasuk birokrasi. Artinya, meskipun terdapat beragam jenis instansi pemerintah, sudah seharusnya instansi-intasnsi tersebut dapat terintegrasi dengan baik. Namun pada kenyataanya, upaya integrasi antar-lembaga di Indonesia kerap kali sulit dilakukan karena berbagai faktor yang memengaruhinya. Ketiadaan payung hukum kerjasama, kurangnya dukungan sarana dan prasarana, bahkan kecemburuan dan ego sektoral antar lembaga yang masih kental dapat menyebabkan gagalnya upaya integasi yang diharapkan

Kondisi tersebut juga dapat kita jumpai dalam konteks kemanan laut. Seperti yang sudah dijelaskan pada bagian sebelumnya, terbentuknya Bakamla di tahun 2014 menyebabkan Indonesia saat ini memiliki 13 lembaga/kementerian yang memiliki wewenang dalam 
pengelolaan keamanan maritim di wilayah nusantara. Jumlah instansi yang sebanyak ini ditambah dengan luasnya perairan yang harus dikelola mengharuskan adanya kerjasama yang terbangun di antara lembaga-lembaga terkait. Sebelum dibentuknya Bakamla, upaya pengintegrasian di antara lembaga-lembaga kelautan diwujudkan dengan pembentukan Badan Koordinasi Keamanan Laut (Bakorkamla) melalui Peraturan Presiden No. 81 Tahun 2005. Badan ini diketuai oleh Menhankam/Pangab dengan susunan keanggotaan yang terdiri dari: Menteri Perhubungan, Menteri Keuangan, Menteri Kehakiman, Jaksa Agung, Kapolri dan Kepala Staf TNI AL. Tugas pokok yang diamanatkan kepada Bakamla di antaranya: mengkoordinir seluruh kegiatan operasional keamanan di laut, memecahkan semua permasalahan pelanggaran hukum di laut, menyelenggarakan kerjasama dengan negara-negara tetangga dengan maksud agar penyelengaraan operasi keamanan di laut senantiasa terjamin daya maupun hasil gunanya secara optimal. Namun pada perjalanannya, pelaksanaan tugas Bakorkamla dinilai masih memiliki beberapa kelemahan. Hal ini dibuktikan dengan fakta bahwa institusi-institusi yang ada di bawah komando Bakorkamla seperti TNI AL, Polair, Bea dan Cukai, Kesatuan Penjaga Laut dan Pantai (Ditjen Perhubungan Laut), Kementrian Kelautan dan Perikanan dan Imigrasi sering berjalan sendiri-sendiri sesuai dengan kewenanganya tanpa mengindahkan fungsi koordinasi yang dimiliki oleh Bakorkamla (Wulansari, 2014). Secara sederhana, upaya pengintegrasian lembagalembaga keamanan laut melalui pembentukan Bakorkamla bisa dikatakan gagal.

Kegagalan upaya pengintegrasian lembaga-lembaga keamanan maritim melalui Bakorkamla kemudian coba diperbaiki dengan pembentukan Bakamla di tahun 2014. Lembaga baru ini dinilai sama sekali berbeda dengan pendahulunya. Sebagaimana dijelaskan dalam Pasal 59 ayat (3) Undang-Undang No. 32 Tahun 2014 tentang Kelautan, Bakamla diberi wewenang untuk melaksanakan patroli keamanan dan keselamatan di wilayah perairan Indonesia dan wilayah yuridiksi Indonesia. Dalam rangka melaksanakan tugas di wilayah perairan Indonesia dan wilayah yuridiksi Indonesia, Bakamla menjalankan fungsi sebagai berikut (Sulistyaningtyas, 2015):

1. Menyusun kebijakan nasional di bidang keamanan dan keselamatan di wilayah laut Indonesia.

2. Menyelenggarakan sistem peringatan dini keamanan dan keselamatan di wilayah laut Indonesia.

3. Melaksanakan penjagaan, pengawasan, pencegahan, dan penindakan pelanggaran hukum di wilayah laut Indonesia.

4. Menyinergikan dan memonitor pelaksanaan patroli perairan oleh instansi terkait.

5. Memberikan dukungan teknis dan operasional kepada instansi terkait.

6. Memberikan bantuan pencarian dan pertolongan di wilayah laut Indonesia.

7. Melaksanakan tugas lain yang masih dalam sistem pertahanan nasional.

Berbagai fungsi dan wewenang yang dimiliki Bakamla di atas juga dimiliki oleh lembagalembaga lain yang lebih dulu ada. Dengan demikian, Bakamla dianggap memiliki derajat yang setara dengan lembaga-lembaga lain seperti TNI AL, Polair, KPLP dan KKP. Berdasarkan hasil wawancara dengan pihak Bakamla, dan mengacu pada teori inter-agency working, sejauh ini interaksi yang terbangun di antara lembaga-lembaga tersebut baru pada tingkat koordinasi. Hal ini ditandai dengan adanya pertukaran informasi kelautan di antara lembaga terkait dan informasi tersebut digunakan sebagai pertimbangan dalam menentukan aktifitas di lembaga masingmasing. Ketiadaan payung hukum untuk dapat saling berbagi sumberdaya meyebabkan interaksi yang terbangun belum bisa menyentuh tingkat kerjasama (cooperating) apalagi kolaborasi. Selain itu, masih adanya kesan ego sektoral juga menyebabkan interaksi yang terjalin belum mampu mencapai derajat yang paling tinggi. 
Derajat kerjasama yang masih rendah di antara lembaga-lembaga tersebut semakin membuktikan sulitnya membangun kemanan maritim Indonesia dengan prinsip Multi Agency Single Task. Hal ini tentu menyebabkan pengelolaan kemanan laut Indoneisa menjadi tidak efektif dan efisien. Penerapan prinsip Multi Agency Single Task tidak hanya berdampak pada proses penegakan hukum semata, tetapi juga menyebabkan kerugian pada pemanfaatan Anggaran Pendapatan dan Belanja Negara (APBN) serta potensi ekonomi kelautan. Setidaknya terdapat beberapa kerugian yang dihadapi Indonesia atas penerapan prinsip ini di bidang kelautan (Wulansari, 2014), antara lain:

1. Citra Indonesia merosot di mata Internasional karena banyak negara mengancam akan menggunakan kapal perang untuk mengawal kapal niaga mereka akibat ketidakmampuan Indonesia memelihara keamanan dan keselamatan di perairan Indonesia.

2. Negara mengalami kerugian sekitar 30 hingga 40 Trilliun Rupiah per tahun karena ilegal fishing, belum termasuk maraknya penyelundupan, kerusakan lingkungan laut dan pantai serta pelayaran.

3. Beban asuransi maritim di perairan Indonesia meningkat karena dinyatakan sebagai wilayah laut paling tidak aman.

4. Uang negara dibelanjakan tidak efisien untuk membiayai pembelian kapal patroli dan pembangunan sistem operasi penegak hukum "Multi Agency Single Task".

5. Masih tingginya angka pelanggaran dan kejahatan di laut (APK) dan lemahnya penegakan hukum disebabkan adanya perbedaan persepsi antara aparat penegak hukum dalam penerapan hukumannya.

Kerugian-kerugian materil dan immateril di atas menuntut adanya reformasi tata kelola sistem keamanan maritim di Indonesia. Salah satu upaya yang dapat dilakukan adalah dengan meninggalkan prinsip Multi Agency Single Task (MAST) dan mengadopsi prinsip baru yaitu Single Agency Multi Task (SAMT). Prinsip ini dinilai tepat untuk mengatasi permasalahan tumpang tindihnya kewenangan di antara berbagai lembaga kelautan yang menyebabkan serangkaian kerugian negara. Prinsip ini akan memberikan berbagai kewenangan kelautan seperti kewenangan regulasi, pengawasan dan pelaksanaan ke dalam satu lembaga saja. Selain memberikan berbagai kewenangan ke dalam satu lembaga, prinsip ini juga berarti menuntut dicabutnya kewenangan-kewenangan serupa dari lembaga lain. Dengan demikian, pemerintah harus menentukan lembaga mana yang akan diberikan kewenagan penuh sekaligus lembaga mana yang kewenangannya akan dicabut. Prinsip seperti ini juga dianut oleh beberapa negara seperti Amerika Serikat dan Malaysia.

Perubahan BAKORKAMLA menjadi Bakamla sejatinya merupakan langkah awal pergeseran prinsip dari MAST ke SAMT. Hal ini diungkapkan sendiri oleh Presiden Joko Widodo pada acara pelantikan Kepala BAKAMLA pada tanggal 12 Februari 2020 yang lalu. Jokowi bahkan menyebut BAKAMLA sebagai embrio dari Indonesian Coast Guard. Berikut petikan ungkapan Jokowi yang dimaksud:

\section{"Ya memang kita harapkan ke depan BAKAMLA menjadi embrio coast guard-nya Indonesia sehingga nanti lembaga yang lain kembali ke institusinya masing-masing dan di laut yang diberikan kewenangan hanya BAKAMLA. Jadi BAKAMLA seperti Indonesian Coast Guard."}

Dari ungkapan tersebut dapat kita lihat dengan jelas bahwa pemerintah akan menjadikan Bakamla sebagai satu-satunya lembaga yang memiliki kewenangan di wilayah perairan Indonesia. Dengan begitu pula kewenangan yang selama ini dimiliki lembaga-lembaga lain akan dicabut untuk memastikan tidak adanya tumpang tindih kewenangan seperti yang selama ini terjadi. Namun demikian, keputusan tersebut tentu tidak dapat dengan mudah dijalankan. 
Pencabutan kewenangan dari lembaga-lembaga kelautan lain tentu berpotensi mendapat penolakan dari berbagai unsur karena sejumlah kepentingan tertentu. Selain itu, pemerintah juga harus terlebih dahulu memastikan bahwa Bakamla memiliki kapasitas untuk menjalankan kewenangan-kewenangan tersebut secara mandiri. Maka dari itu, dibutuhkan persiapan yang sangat matang sebelum akhirnya hal itu dapat dilaksanakan untuk menghindari permasalahanpermasalahan baru di masa yang akan datang dan memastikan keamanan wilayah laut Indonesia dapat berjalan baik di bawah kendali Bakamla.

\section{Reformasi Birokrasi 4.0 Lembaga Keamanan Maritim: Bakamla}

Seiring dengan tuntutan perkembangan zaman yang selaras dengan kemajuan teknologi telah mendorong birokrasi untuk dapat beradaptasi. Keberadaan Revolusi Industri 4.0 meyebabkan setiap lembaga dan individu berusaha menyesuaikan diri dengan kecanggihan teknologi seperti Internet of Things, Big Data, Artificial Intelligence, dan Computerized Autonomous. Berbagai hal tersebut juga menyebabkan berkembangnya inovasi teknologi yang merupakan suatu keniscayaan. Bagi birokrasi, reformasi 4.0 adalah kebutuhan sebagaimana desakan terhadap pelayanan publik yang profesional, berintegritas, dan efisien. Bahkan keberadaan Pandemi COVID-19 telah merubah kebiasaan dalam pengalaman kerja yang baru dengan serba digital.

Menurut Dodi Faedlulloh, dkk (2020), reformasi birokrasi merupakan keinginan untuk melakukan perubahan dalam bidang administrasi agar dapat meningkatkan kinerja dari aparatur negara dan menyempurnakan kelembagaan yang lebih efektif. Sebagai upaya yang dikehendaki, reformasi birokrasi tidak hanya sekadar merubah kebiasaan, namun memiliki cara berpikir yang lebih inovatif, produktif, dan kompetitif yang menyesuaikan dengan transformasi global. Tatakelola pemerintaan yang baik tidak hanya harus bisa menguasai teknologi, melainkan juga berwawasan luas dan berdaya saing agar mendukung tujuan pembangunan nasional. Unsur kecepatan, efisien, dan efektif adalah beberapa hal yang menjadi kebutuhan seiring dengan disrupsi teknologi 4.0. Hal tersebut menyebabkan adanya kebutuhan terhadap lingkungan birokrasi yang dapat menyelesaikan berbagai masalah dengan cepat, tepat fungsi, tepat proses, dan tepat sasaran.

Guna mewujudkan hal tersebut diperlukan adanya pendekatan birokrasi yang sistematik untuk mewujudkan tata kelola pemerintahan yang profesonal dan melayani publik secara maksimal. Birokrasi keamanan maritim sebagai wujud keberadaan Pemerintah Indonesia harus mampu menjawab tantangan masa kini dan transformasi lingkungan yang mengutamakan pada efisiensi dan evektivitas agar menghasilkan peranan nyata kepada masyarakat dalam rangka melindungi kedaulatan dan keamanan wilayah negara. Lembaga pemerintahan yang memperoleh pendanaan berasal dari dana APBN negara dan pajak rakyat perlu memberikan pelayanan yang prima guna mencapai kepuasan publik dan meningkatkan daya saing Indonesia dengan melakukan serangkaian upaya / tahapan guna melaksanakan reformasi birokrasi 4.0.

Terdapat tiga bagian yang menjadi penting diperhatikan sebagai bentuk implementasi pemikiran reformasi birokrasi 4.0, seperti pembaruan, penggunaan teknologi, dan kerjasama. Pembaruan merupakan salah satu unsur penting dalam upaya menghasilkan perubahan dan perbaikan melalui pencarian, pembentukan, dan penerapan berbagai ide baru (Sorensen, 2011). Pembaruan tidak hanya dilakukan dalam struktur semata, melainkan juga upaya pelayanan publik dengan menyelaraskan antara internal lembaga, stakeholder, dan masyarakat. Kemudian penggunaan teknologi sebagai upaya memudahkan dan memaksimalkan tugas fungsi lembaga melalui penggunaan perangkat lunak dan keras sesuai dengan teknologi terbaru. Keberadaan pemakaian infrastruktur teknologi juga perlu didukung oleh kepemimpinan, keterampilan para birokrat, pemeliharaan, dan peningkatan keamanan (Nurrohmah dkk, 2017). Terakhir, kerjasama 
antar pihak diperlukan untuk menghindari adanya konflik dan tumpang tindih antar institusi pemangku kepentingan. Kerjasama juga penting dalam upaya mendukung rencana dan target pemerintah yang memerlukan kolaborasi lintas lembaga, kementerian, dan pemerintah daerah (Ansell, 2008).

Rencana mewujudkan tata kelola pemerintahan kelas dunia juga perlu memperhatikan pembangunan maritim. Masa depan Indonesia bukan hanya pada daratan, melainkan pada lautan yang perlu diperhatikan lebih lanjut dalam hal pembangunan, perlindungan, dan keamanan perairan laut. Saat ini merupakan momentum yang tepat untuk melihat bahwa lautan adalah kunci masa depan kemajuan bangsa. Muncul pula kesadaran bahwa sumber daya kelautan perlu dimanfaatkan dengan lebih optimal untuk mencapai kesejahteraan masyarakat yang berkelanjutan (Hutagalung dkk, 2019).

Berikutnya, dalam kaitannya agenda reformasi birokrasi Bakamla sebagai pelayan publik memiliki beberapa pikiran pokok, diantaranya: akuntabel, kapabel, dan pelayanan publik yang prima. Akuntabel dapat dinilai dari penataan kelembagaan dan Sumber Daya Manusia (SDM) sesuai dengan fungsinya dan dapat dipertanggung jawabkan. Lalu kapabel berarti birokrasi dapat berarti bahwa birokrasi dapat diandalkan dalam menangani semua kebutuhan masyarakat sehingga dapat melaksanakan pembangunan dan berdaya saing. Sementara pelayanan publik adalah titik puncak dalam kualitas pelayanan yang prima, professional, dan terukur keberhasilannya (Bakamla, 2020).

Beberapa tahapan yang perlu dilaksanakan dalam mengimplementasikan reformasi birokrasi 4.0 oleh Bakamla, diantaranya:

1. Upaya evaluasi terhadap sarana dan prasarana yang dimiliki oleh lembaga.

Berkaca pada realitas wilayah laut Indonesia yang luas dan memiliki sepuluh (10) perbatasan, tentunya memerlukan dukungan sarana dan prasarana yang memadai. Sementara kenyataannya masih banyak tindak kejahatan dan pelanggaran wilayah yang seringkali dilakukan oleh warga asing maupun masyarakat setempat. Apabila kita melihat realitas masih banyak kekurangan terhadap jumlah kantor operasi, SDM, piranti lunak, alat persenjataan, dan dukungan logistik. Berbagai tantangan tersebut berkorelasi terhadap rendahnya capaian kinerja dan keberhasilan operasi.

2. Tindakan penataan manajemen dilaksanakan semenjak rekrutmen tenaga SDM, internalisasi budaya kerja, pelatihan, keteladanan, penilaian komitmen, dan penilaian ketercapaian kerja.

Belum seimbangnya jumlah kebutuhan kepegawai dengan realitas, memerlukan rekrutmen, beban kerja, dan kejelasan karier yang disesuaikan dengan kompetensi yang diperlukan. Ada juga kecenderungan dalam pemikiran birokrasi di Indonesia bahwa birokrat dilayani oleh masyarakat menjadi tantangan terbesar. Perlu adanya perubahan mendasar dalam paradigma bahwa birokat merupakan pelayan rakyat karena memperoleh penghasilan dari hasil pajak yang dibayarkan masyarakat. Aparatur keamanan maritim harus memahami sepenuhnya visi dan misi terkait pencegahan pelanggaran hukum dan pengamanan maritim di Indonesia. Selain budaya kerja, pelatihan seperti standar operasi, keterampilan navigasi, panataran penggunaan teknologi, bimbingan teknis, dan pendidikan dasar penggunaan persenjataan menjadi penting dilaksanakan.

3. Pengorganisasian dalam tata kelola keamanan maritim penting diimplementasikan.

Dalam mewujudkan visi "Indonesia Maju" sulit diimplementasikan apabila terjadi tumpang tindih kewenangan dan persaingan antar lembaga. Perlu adanya kejelasan batasan dan kewenangan tiap organisasi keamanan laut di Indonesia berdasarkan Tugas Pokok dan Fungsi (Tupoksi) yang jelas. Keberadaan Bakamla, TNI AL, Polairud, Kementerian Kelautan dan Perikanan (KKP), dan Ditjen Bea Cukai yang melaksanakan pengamanan laut di Indonesia 
seringkali menghadapi kendala overlapping dan belum adanya koordinasi rutin.

4. Penguatan organisasi keamanan maritim penting setelah dilaksanakannya evaluasi dilajutkan perbaikan manajemen dan koordinasi lintas lembaga dalam operasi patroli maritim.

Tindakan yang dilakukan dapat dengan membangun infrastruktur kantor dan markas di berbagai wilayah, penggunaan sarana komunikasi satelit, pemanfaatan deteksi dini, pengadaan alat persenjataan, penyediaan bahan bakar, dan kerjasama dengan lembaga domestik maupun internasional.

5. Pengawasan kinerja birokrat yang akuntabel, kapabel, dan menjadi pelayan publik yang prima.

Upaya kontrol terhadap pencegahan korupsi, penyalahgunaan kewenangan, dan capaian keberhasilan perlu dilaksanakan. Merujuk hal tersebut, dalam setiap tahun maupun lima tahun sekali perlu adanya penilaian dan evaluasi terhadap komponen pelayanan dan kepuasan publik. Sistem rotasi jabatan, penilaian berbasis resiko, pencegahan tindakan koruptif, dan optimalisasi penggunaan anggaran dapat menjadi indikator dalam sisi akuntabel. Kesesuaian operasi / tindakan terhadap kebutuhan dan pengukuran keberhasilan harus dilaksanakan agar dapat menyelesaikan setiap permasalahan merupakan unsur penting dalam kapabel. Sementara penyederhanaan birokrasi, transparansi, audit independen, sistem promosi dan demosi menjadi parameter penting guna mewujudkan pelayanan publik yang prima (Katharina, 2019).

Lebih lanjut dalam menentukan keberhasilan reformasi birokrasi pada Bakamla sebagai lembaga keamanan maritim di Indonesia terdapat beberapa aspek penting, seperti:

Pertama, memiliki komitmen yang kuat oleh pimpinan dan seluruh pegawai birokrat tersebut untuk melaksanakan reformasi birokrasi. Apabila komitmen hanya dilakukan oleh segelintir pimpinan, sementara tidak menyentuh seluruh level dari lembaga tersebut, tentunya akan sulit dan membutuhkan waktu yang lama untuk diimplementasikan. Perlu adanya kesadaran dan kesamaan paradigma dalam mengimplementasikan reformasi birokrasi sebagai fokus prioritas organisasi, ketimbang hanya sebagai perintah dari lembaga yang lebih tinggi. Komitmen dan fokus yang kuat akan menentukan keberhasilan pelaksanaan visi dan misi lembaga keamanan maritim tersebut untuk melindungi seluruh wilayah perairan Indonesia.

Kedua, penanaman dan penghayatan terhadap seluruh program reformasi birokrasi yang berhubungan dengan revolusi mental dari para birokrat. Bahwa sebuah birokrasi tidak dapat berjalan hanya dalam periode waktu tahun tertentu, melainkan dalam jangka waktu yang panjang selama negara ini berdiri. Merujuk pada hal tersebut, upaya reformasi birokrasi harus dijalankan secara simultan dan berkelanjutan untuk mencapai target yang telah ditentukan. Seluruh pihak yang tergabung dalam lembaga tersebut perlu memprioritaskan pada kepentingan bangsa dan negara dibandingkan keinginan pribadi tertentu hingga pada ujungnya dapat menjaga keamanan laut Indonesia secara maksimal.

Ketiga, penyederhanaan birokrasi, efisiensi anggaran, dan memaksimalkan sarana prasarana lembaga. Apabila dahulu kecenderungan bahwa lembaga pemerintah berbelit-belit dan cenderung 'gemuk', sebaliknya saat ini harus dapat mengutamakan pada efektivitas dan efisiensi dalam menjalankan tugas. Diperlukan adanya simplikasi terhadap birokrasi yang panjang dan menghambat pencapaian tujuan organisasi. Sisi anggaran juga perlu memperhatikan pada prioritas kebutuhan dan realitas kondisi bangsa yang sudah bukan saatnya lagi terjadi pemborosan dalam pemanfaatan dana negara. Sementara keberadaan sarana dan prasarana perlu digunakan dengan sebaik mungkin, baik dalam hal melengkapi kebutuhan maupun pemeliharaannya. Diharapkan jika ketiga hal tersebut dilaksanakan dengan serius, tentunya dapat mendukung reformasi birokrasi dengan sebaik mungkin. 
Keempat, reformasi birokrasi tidak hanya sebatas menjadi prioritas kelembagaan, melainkan suatu kebutuhan dan kebiasaan. Apabila seluruh aparatur birokrasi keamanan telah terbiasa dalam menjalankan tugasnya secara efektif dan efisien sesuai dengan ketentuan yang berlaku, tentunya hal tersebut akan menjadi budaya kerja. Selanjutnya reformasi birokrasi akan berjalan secara otomatis dan berkelanjutan yang dapat mewujudkan sebuah kondisi birokrasi yang ideal dan semakin baik.

\section{Capaian Reformasi Birokrasi 4.0 Bakamla}

Penulis telah merangkum beberapa capaian yang telah dilaksanakan Bakamla RI dalam usaha reformasi birokrasi dengan menyesuaikan pada disrupsi teknologi 4.0 pada sisi keamanan maritim, antara lain:

\section{a) Capaian Manajemen}

1. Manajemen SDM yang baik

Dalam Rencana Pembangunan Jangka Panjang Nasional (RPJPN) 2005-2025 dan Rencana Pembangunan Jangka Menengah Nasional (RPJMN) 2020-2024, Bakamla telah memiliki tiga tahapan, yakni: Penguatan birokrasi (2010-2014), Peningkatan profesionalitas (2015-2019), dan Mewujudkan Pemerintahan kelas dunia (2020-2024) (Bakamla, 2020). Bakamla telah berusaha membuat kelembagaan yang mantap dengan pengembangan SDM sejak penerimaan pegawai yang terintegrasi dengan Seleksi Calon Pegawai Negeri Sipil (CPNS), pelatihan dan pendidikan dasar, internalisasi budaya kerja berdasarkan visi misi, penataran tata laksana, penataan SDM sesuai kompetensi, pemberian keteladanan oleh pimpinan, pembinaan karier, penilaian capaian, dan jaminan pensiun (Laras Post Online, 2019).

\section{Implementasi e-Government}

Dalam pelaksanaan setiap kegiatan, baik proses kerja, pengadaan barang, dan pengawasan dilakukan secara terintegrasi digital. Adanya penilaian kinerja pegawai pada setiap unit kerja dalam e-sistem yang tercatat dan real time. Upaya penerapan tata Kelola yang berbasis Teknologi Informasi (TI), moderen, dan terdigitaliasi menjadi standar kerja yang umum bagi Bakamla (Hozairi, 2018). Lalu Bakamla menggunakan e-government, e-arsip, e-catalog, eprocurement, dan pengintegrasian operasi patroli (Rusfandi, 2017), sistem pelayanan publik, survei kepuasan masyarakat, dan publikasi secara digital pada situs resmi maupun media sosial (Bakamla, 2020). Adanya pemanfaatan berbagai bentuk teknologi oleh Bakamla ini tidak hanya bisa memudahkan operasional institusi, namun pada jangka panjang mendukung belanja dan investasi, pembangunan nasional, keamanan maritim, dan pertahanan wilayah Pemerintah Indonesia.

\section{Pelaksanaan Good Governace}

Seiring dengan sasaran Revolusi Mental oleh Pemerintah Indonesia, Bakamla berusaha melaksanakan tata kelola yang baik bersama Kementerian Pendayagunaan Aparatur Negara dan Reformasi Birokrasi (PANRB). Salah satu bentuknya adalah dengan peningkatan peran Bakamla bersama masyarakat dalam rangka Collaborative Governance dengan menggunakan teknologi informasi dan media sosial agar tidak hanya memberikan pengetahuan cinta tanah air, melainkan juga pelaporan terhadap kejahatan dan pengawasan kinerja Bakamla. Lalu, Bakamla melakukan monitoring terhadap pelayanan publik dengan indeks yang meningkat setiap tahunnya, misalnya pada 2018 memperoleh skor 44,62 menjadi 50,48 pada 2019 (JPNN, 2018). Selain itu, Bakamla berkoordinasi dengan kementerian lembaga dalam dan luar negeri dalam yang terkait dengan keamanan laut, seperti Penjaga Pantai Amerika Serikat, Jepang, dan Australia (Iswardhana, 2021). 


\section{Implementasi Budaya Maritim}

Bakamla menjadi penggerak utama dalam mensosialisasikan budaya maritim kepada masyarakat luas. Bakamla juga berperan dalam program ekonomi maritim dan pemberdayaan masyarakat pesisir dengan berkoordinasi bersama KKP. Lalu, Bakamla mengajak masyarakat untuk berperan aktif dalam menjaga keamanan laut, baik saat menangkap ikan, pemanfaatan kekayaan alam, pelaporan tindak kejahatan, pemberitahuan kecelakaan, dan notifikasi bencana alam. Selain itu, Bakamla bekerjasama dengan lembaga lainnya dalam pencegahan terhadap kejahatan di laut, seperti: pengedaran narkoba, penyalahgunaan pulau untuk kegiatan terorisme, penyelundupan barang ilegal (Humas Kemenko Polhukam RI, 2021). Peran serta Bakamla dalam menggalakkan budaya maritim secara luas kepada masyarakat pada akhirnya bisa mewujudkan ekonomi inklusif, pariwisata, sistem transportasi dan logistik, pemanfaatan SDA berbasis maritim yang berkelanjutan.

\section{b) Capaian Koordinasi}

\section{Koordinasi Produksi Perikanan}

Bakamla berkoordinasi dengan pemerintah daerah (pemda) tingkat provinsi dan kabupaten di seluruh Indonesia yang memiliki wilayah pesisir dalam rangka produksi perikanan yang berkelanjutan (Gatra, 2021). Selain itu, Bakamla juga berkoordinasi dengan KKP dalam rangka pengelolaan ekonomi maririm dengan melakukan sosialisasi penggunaan alat tangkap sesuai ketentuan hukum. Tercatat kolaborasi kedua lembaga ini menghasilkan Pembangunan 100 sentra perikanan terpadu dan pembuatan 24 pelabuhan strategis (Pramugar, 2019).

\section{Koordinasi Tata Ruang Pesisir}

Bakamla bersama dengan Pemda dan Kementerian Kementerian Agraria dan Tata Ruang/Badan Pertanahan Nasional (ATR/BPN) dalam mendesain tata ruang wilayah pesisir dan pembangunan ekonomi maritim berkelanjutan (Kementerian ATR BPN, 2021). Bahwa pulaupulau di Indonesia, utamanya wilayah perbatasan dan terluar telah menjadi perhatian pemerintah terkait perlindungan dan pemanfaatan wilayah pesisir. Sektor maritim juga menjadi fokus terkait penataan ruang laut, perizinan perikanan, pemanfaatan sumber daya, dan pencegahan kerusakan biota laut.

\section{Koordinasi Keamanan laut}

Bakamla dengan KKP sudah menyusun peta kelautan dengan berbasis pada realitas perbatasan. Lalu, kedua lembaga ini juga melaksanakan pemberantasan illegal, unregulated dan unreported fishing yang dilakukan oleh warga negara dan nelayan asing ilegal (Kompas, 2020). Dalam upaya menjaga kedaulatan wilayah laut Indonesia, Bakamla melakukan penindakan terhadap berbagai kapal yang diduga melakukan Tindakan pelanggaran hukum, sementara KKP melaksanakan penyidikan dan penegakan hukum. Adanya kolaborasi kedua lembaga keamanan laut pemerintah tersebut menunjukkan upaya para aparat penegak hukum di berbagai wilayah Indonesia terus berupaya memberantas bermacam praktik kejahatan di laut (Tempo, 2021).

\section{Koordinasi Penengakan Hukum}

Bakamla bekerjasama dengan berbagai lembaga otoritas keamanan maritim di Indonesia, antara lain TNI, Kepolisian RI, KKP, dan Kementerian Hukum dan HAM dalam pelaksanaan penegakan hukum (Dirjen Sumber Daya Kelautan KKP, 2021). Berdasarkan Mou antara Bakamla dengan TNI AL, KKP, POLRI telah dilakukan pembagian yurisdiksi laut dan harmonisasi hukum laut. Apabila terjadi tindak kejahatan dan pelanggaran wilayah, Bakamla akan melakukan penangkapan yang selanjutnya dilimpahkan proses penuntutan kepada lembaga penegak hukum. Sementara jika terjadi pelanggaran oleh militer asing, maka akan didukung oleh TNI AL (Antaranews, 2021). 


\section{Koordinasi Operasi Patroli dan Wilayah Perbatasan}

Bakamla melakukan koordinasi dengan TNI AL, Kementerian Luar Negeri (Kemlu), dan Kementerian Pertahanan (Kemhan) dalam upaya pengamanan laut di wilayah perbatasan. Terhadap daerah-daerah yang mengalami klaim dari negara tetangga akan diserahkan pada TNI AL dan Kemlu untuk melakukan perundingan. Selanjutnya, dilaksanakan patroli dan pengamanan laut terhadap pemanfaat Sumber Daya Alam (SDA) pada wilayah Zone Ekonomi Eksklusif (ZEE). Selain itu, bersama dengan Kemhan Bakamla melakukan pembangunan wilayah perbatasan dengan pendekatan ekonomi maritim yang berkelanjutan (Munaf, 2015).

\section{Simpulan}

Tata kelola keamanan maritim yang dijalankan Indonesia saat ini dinilai kurang efektif dan efisien. Upaya perbaikan yang dilakukan selama ini belum mampu menyelesaikan berbagai permasalahan yang menghambat kemajuan Indonesia sebagai negara kepulauan. Oleh karena itu, tumpang tindihnya sejumlah peraturan perundang-undangan dan lembaga yang berwenang di perarian Indonesia dipandang sebagai penyebab utama dari permasalahan-permasalahan yang ditemukan. Pola interaksi yang terjalin antar-lembaga berwenang juga hanya sebatas koordinasi insidentil. Hal ini menuntut adanya reformasi mendasar dalam tata kelola keamanan maritum di Indonesia. Pembentukan Bakamla menjadi sebuah langkah awal yang tepat guna mentransformasikan tata kelola keamanan maritim dari yang sebelumnya menganut prinsip Multi Agency Single Task menuju prinsip baru Single Agency Multi Task. Namun langkah awal ini tidak akan berpengaruh apa-apa tanpa diikuti langkah-langkah berikutnya guna mencapai apa yang dicita-citakan.

Bahwa reformasi birokrasi 4.0 adalah sebuah kebutuhan penting dalam mewujudkan tata kelola keamanan maritim Indonesia yang profesional, berintegritas, dan efisien. Birokrasi tidak dapat menjalankan tugasnya dengan maksimal apabila masih memiliki tantangan dan permasalahan secara internal. Maka diperlukan berbagai upaya, seperti: evaluasi terhadap sarana dan prasarana, penataan manajemen, pengorganisasian dalam tata kelola keamanan maritim, penguatan organisasi keamanan laut, dan pengawasan kinerja.

Bakamla RI sebagai salah satu lembaga keamanan wilayah laut di Indonesia berupaya bertransformasi institusi menjadi profesional, berintegritas, efisien dalam Pelayanan Publik. Bakamla melakukan berbagai perbaikan di atas untuk mencapai visi Indonesia Maju yang tidak hanya menggunakan pendekatan pada penegakan hukum pada institusi ini sendiri, melainkan juga melakukan koordinasi lintas lembaga, kolaborasi bersama masyarakat, dan pemberdayaan ekonomi maritim rakyat. Terdapat berbagai tahapan dan capaian yang telah dilaksanakan Bakamla dalam rangka mewujudkan reformasi birokrasi 4.0 dalam rangka perlindungan kedaulatan dan keamanan maritim Indonesia. 


\section{Referensi}

Apriani, D.A. (2019). Integrasi Tata Kelola Kebijakan Pembangunan Kelautan Berkelanjutan. Jurnal Rechtsvinding, 8 (2).

Ansell, C., Gash, A. (2008). Collaborative Governance in Theory and Practice. Journal of Public Administration Research and Theory, 18 (4).

Antaranews. (2021). Bakamla Paparkan Kondisi Keamanan Laut Di Tengah Pandemi COVID19. [Online] Available from: https://www.antaranews.com/berita/1754457/bakamlapaparkan-kondisi-keamanan-laut-di-tengah-pandemi-covid-19\#mobile-src [Accessed 8th August 2021].

Ardiansyah, A. (2020). Bakamla Ungkap Sejumlah Ancaman Keamanan Laut Indonesia. [Online] Available from: https:/www.voaindonesia.com/a/bakamla-ungkap-sejumlahancaman-keamanan-laut-indonesia/5450902.html [Accessed 8th August 2021]

Badan Keamanan Laut Republik Indonesia. (2020). Road Map Reformasi Birokrasi Badan Keamanan Laut Republik Indonesia. Jakarta: Bakamla.

Bisnis Tempo.co.id. (2021). KKP Sidik 3 Kapal Illegal Fishing yang Ditangkap Bakamla. [Online] Available from: https://bisnis.tempo.co/read/1420575/kkp-sidik-3-kapal-illegalfishing-yang-ditangkap-bakamla/full\&view=ok [Accessed 8th August 2021]

Budiman, A. (2016). Urgensi Pengaturan Masalah Keamanan Laut di Indonesia. Jurnal Pemerintahan Dalam Negeri, 8 (21).

Butcher, J.G., Elson, R E. (2017). How did Indonesia become an archipelagic state? [Online] Available from: https://www.aspistrategist.org.au/indonesia-became-archipelagic-state/ [Accessed 7th August 2021]

Direktorat Jenderal Pengelolaan Ruang Laut. (2020). Konservasi Perairan Sebagai Upaya menjaga Potensi Kelautan dan Perikanan Indonesia. [Online] Available from: https://kkp.go.id/djprl/artikel/21045-konservasi-perairan-sebagai-upaya-menjaga-potensikelautan-dan-perikanan-indonesia [Accessed 7th August 2021].

Direktorat Jenderal Sumber Daya Kelautan KKP. (2021). Koordinasi Badan Keamanan Laut (Bakamla) dengan Pangkalan PSDKP. [Online] Available from: https://kkp.go.id/djpsdkp/pangkalanbatam/galeri/8935-koordinasi-badan-keamanan-lautbakamla-pangkalan-batam [Accessed 9th August 2021]

Faedlulloh, D., Maarif, S., Meutia, I.F., Yulianti, D. (2020). Birokrasi Dan Revolusi Industri 4.0: Mencegah Smart ASN Menjadi Mitos dalam Agenda Reformasi Birokrasi Indonesia. Jurnal Borneo Administrator, 16 (3).

Gatra. (2021). Atasi Isu Keamanan Laut Bangun Koordinasi Bakamla-Pemda. [Online] Available from: https://www.gatra.com/detail/news/506477/hukum/atasi-isu-keamananlaut-bangun-koordinasi-bakamla--pemda [Accessed 10th August 2021].

Himmelman, A.T. (2002), Collaboration for Change: Definitions, Decision-Making Models, Roles, and Collaboration Process Guide. Minneapolis, Himmelman Consulting.

Hozairi, B., Laksmono, H., Tukan, M. (2018). Pengembangan E-Monitoring Untuk Badan Keamanan Laut Indonesia. SEMINAR MASTER 2018 PPNS.

Humas Kemenko Polhukam RI. (2021). Rapim Bakamla Menko Polhukam Tekankan Pentingnya Sinergi dan Koordinasi. [Online] Available from: https://polkam.go.id/rapim-bakamlamenko-polhukam-tekankan-pentingnya-sinergi-koordinasi/ [Accessed 10th August 2021].

Hutagalung, S.M., Hutabarat, L., Simatupang, R.H. (2019). Tantangan Kerjasama Keamanan Di 
Perairan Asean oleh Indonesia. Jakarta, Fakultas Ilmu Sosial Dan Ilmu Politik Universitas Kristen Indonesia.

Iswardhana, M.R. (2021). Kerjasama Maritim Indonesia-Amerika Serikat sebagai Implementasi Politik Poros Maritim Indonesia: BAKAMLA-US Coast Guard. Jurnal Dinamika Pemerintahan, 4 (1).

JPNN. (2018). Bakamla Sosialisasikan Reformasi Birokrasi di Tiga Zona. [Online] Available from: https://www.jpnn.com/news/bakamla-mensosialisasikan-reformasi-birokrasi-di-tigazona [Accessed 9th August 2021].

Katharina, R. (2019). Reformasi Birokrasi Indonesia dan Revolusi Industri 4.0. Jakarta, Yayasan Pustaka Obor Indonesia.

Kompas. (2020). Atasi Ancaman Asing, 13 Institusi Bekerja Sama Awasi Laut Natuna Utara. [Online] Available from: https://nasional.kompas.com/read/2020/02/21/10305371/atasiancaman-asing-13-institusi-bekerja-sama-awasi-laut-natuna-utara [Accessed 8th August 2021].

Kusuma, A.W., Prakoso, L.Y., Sianturi, D. (2019). Sinergitas Komando Armada I dan Badan Keamanan Laut Republik Indonesia dalam Strategi Pertahanan Laut Guna Memberantas Kejahatan Lintas Negara di Selat Malaka. Jurnal Prodi Strategi Pertahanan Laut, 5 (2).

Kementerian ATR BPN. (2021). Koordinasi Lintas Sektor Menjadi Kunci Atasi Permasalahan di Pulau-Pulau Kecil Terluar dan Pesisir. [Online] Available from: https://www.atrbpn.go.id/?menu=baca\&kd=bn7PHsDN//udwAnR/QaSwGDvWswfVOS/J Lpio5Qs3fN49YPOv0OH9uu+jv3ikkXz [Accessed 9th August 2021].

Laras Post Online. (2019). Wujudkan Good Governance Kabakamla Tegakkan Disiplin Personel. [Online] Available from: https://www.laraspostonline.com/2019/02/wujudkan-goodgovernance-kabakamla.html[Accessed 8th August 2021].

Munaf, D.R., Sulistyaningtyas, T. (2015). Sistem Operasi Tersinergi Bakamla Sesuai Dengan Undangundang Nomor 32 Tahun 2014 Tentang Kelautan. Jurnal Sosio Teknologi, 14 (3).

Nainggolan, P.R. (2016). Kebijakan Poros Maritim Dunia Joko Widodo Dan Implikasi Internasionalnya. Jurnal Politica, 7 (1).

Nurrohmah, I., Dewi, M.A., Sahadi, N. (2017). Measuring the e-Government Maturity in Indonesia using the Ranking of e-Government of Indonesia (PeGI). American Scientific Research Journal for Engineering, Technology. and Sciences (ASRJETS, 32 (1).

Nurdiansyah, D.R. (2018). Merumuskan Definisi Keamanan Maritim. Jakarta, Sekolah Staf dan Komando Angkatan Laut.

Pramugar, R.N. (2019). Antara Bakamla Dan Satgas 115. Jakarta, Pusat Transformasi Kebijakan Publik.

Ramadhan, A., Winarno, D.W. (2020). Tinjauan Yuridis Kewenangan Badan Keamanan Laut dalam Menjaga Keamanan Laut. Jurnal Discretie, 1 (1).

Rusfandi, D.N. (2017). Pertukaran Informasi Berbasis Early Warning System dalam Penanganan Illegal Fishing. Jurnal Prodi Keamanan Maritim, 3 (3).

Santosa, M.A. (2020) Penguatan Sistem Keamanan Laut. Indonesia Ocean Justice Initiative Policy Brief 2. [Online] Available from: https://oceanjusticeinitiative.org/mdocsposts/policy-brief-ioji-tentang-penguatan-sistem-keamanan-laut/ [Accessed 8th August 2021]. 
Sorensen, E. dan Torfing, J. (2011). Enhancing collaborative innovation in the public sector. Journal of Administration and Society, 43 (8).

Sulistyaningtyas, T.S., Munaf, D.R. (2015) Sinergitas Paradigma Lintas Sektor Di Bidang Keamanan dan Keselamatan Laut. Jakarta, Penerbit PT Gramedia Pusaka Utama.

Wulansari, E.M. (2014). Penegakan Hukum di Laut dengan Sistem Agency Multy Tasks. Jurnal RechtsVinding Online. 